\title{
Development of the Students' Cultural Identity in the Course of Exhibition Activities of the University Art Museum
}

\author{
Semyon D. Voroshin* \\ South Ural State University \\ National Research University \\ 76 Lenin, Chelyabinsk, 454080, Russia
}

Received 23.06.2017, received in revised form 07.07.2017, accepted 14.07.2017

This work deals with the phenomenon of the studentship's cultural identity and defines the role of the university museum in its generation. The Hall of Arts of the South Ural State University is given as an example of the influence of exhibition activities on the development of different levels of the studentship's cultural identity. Exhibitions of South Ural artists held in the university have been analyzed and their role in the national and regional aspects of the university's cultural life has been demonstrated.

Keywords: university museums, art exhibitions, generation of cultural identity, South Ural artists.

DOI: 10.17516/1997-1370-0117.

Research area: theory and history of culture.

Modern issues of humankind represent one of the most important areas of interest for cultural studies. Preserving the country's unique culture is even more relevant during the period of globalization. This is important not only for the nation as a whole, but each individual in particular since self-identification with the country's culture is one of the key elements of a personal identity. Insight into the person's involvement with the cultural past and present of his/her country is built, among other things, through the awareness and involvement with the traditions of one's native land [2-3].

Regional cultural identity describes person's identification with a social group, of which he/ she is a member, based on common territorial, social and mental features [1; 5, p. 34]. Identity enables the existence of social groups resulting, in its turn, from the selected traditions that fill it up and ensure emotional involvement with this society. In modern research, basic elements of cultural identity are spiritual, national, political, territorial and state self-identifications [12]. An aggregate of factors fosters the formation and further development of the regional cultural identity. First of all, this is the common historical past that enables the existence of this community and is reflected in its myths, legends and symbols. Another important factor is the common culture, which is based on the experience of cohabitation

(C) Siberian Federal University. All rights reserved

* Corresponding author E-mail address: svoroshin@mail.ru 
of individuals and reflects the main principles of relations between people inside a region $[5$, c. 44]. Another factor is the attitude towards outstanding leaders, respect to local heroes and their memorization. The establishment of the cultural self-identification of students as one of the vast youth groups deserves special attention. Higher educational establishments and their museum facilities play an important role in building students' awareness of the characteristic features of their region.

Let us consider the process of the studentship's cultural identity development by the example of exhibition activities of the Art Museum of the South Ural State University (SUSU). Its activities are the subject of a number of research studies [6-11; 13-14]. During 14 years of existence of the structural division of the Art Museum - exhibition Hall of Arts, - it has housed 122 expositions with 34 dedicated to the creative work of modern professional artists of the region. The exhibitions were made up using the collections of the Chelyabinsk State Museum of Fine Arts and Art Museum of SUSU, museum of the Chelyabinsk State Institute of Culture and collectors Yu.T. Ageev, O. G. Kalnin, V.A. Romashov, N. I. Perevozchikov and artists' studios from.

Exhibitions of Ural artists promote the generation of the studentship's cultural identity on different levels: global, national, regional and spiritual. The most important group of exhibitions promotes the involvement with panhuman phenomena, historical process of art development on a global scale. Exhibition dedicated to one work - ceramic board "Centuries Go by" by Aleksander Petrovich Kudryavtsev became a unique event. The friso is divided into seven compositions, each of which has its own name and refers to a particular cultural and historical epoch. Compositions "Khesira Builder" and "Silenes Squeezing out Grape Juice to the sounds of Aulos" symbolize the beginning of a long way of the human culture (Ancient Egypt and Antiquity). The "Savior" unit is visuals of quotes from the Byzantine and Old Russian art. The "I Remember This World" unit - author's self-portrait surrounded by landmark "attributes" of the centuries-old history of art - breaks the chronological order of the friso. "The Old Slave" is the next composition unit, which simply but concisely expresses the heritage of the WestEuropean art of the Renaissance. The fragment "Shadows of the Northern Garden" contains the artefacts from the Golden Age of the Russian culture of A. Pushkin's times. The friso ends with the composition "I was a Guest to the Earth Back Then" with a portrait of poet A.A. Akhmatova in the center surrounded by replicas from works of artists of the XX century: P. Picasso, A. Modigliani, P.N. Filonov, K.S. Malevich, F. Leger. Akhmatova defines the present as a pitchfork and makes one responsible for one's views and opinions. The board is abundant in quotes, replicas and motifs re-created by the artist from renowned samples. He features his own natural style and imagery, using which the author managed to "combine the uncombinable" in one major work and attain unity while working on the artistic materials from different times and of different genres, which resulted in an integral work of art saturated with meanings and symbols. Later on, the Hall of Arts housed expositions of the sculptor's wife, Lyudmila Kudryavtseva - "The Holy History" and "Link of Times" depicting iconographic scenes, St. Petersburg landscapes and images of the Silver Age [4].

Identity has many layers. Let us consider one of its most complex aspects, spirituality. Exposition by South-Ural artists "Who Are We? Where Are We Going?" showcased the collection of graphics by Ekaterina and Aleksander Savochkin. The artists' subjects 
are of philosophical and Biblical nature. The graphics exhibited reflects the maturity and depth of the internal feeling of Old Testament texts. The audience can clearly feel that the author is attracted by the depicted subjects which is enhanced by bold graphic experiments and high self-discipline. The next exposition of this direction was the one called "In Anticipation of Christmas" by Vladislav Vaganov. The author deals with eternal themes - life of Christ, Blessed Virgin, New Testament events. The artist depicts them through his vision. In his creative search, the painter has chosen the irrational and intuitive perception and reflection of the world. His paintings embody his visions and dreams. Vaganov's exposition was very important to the Hall of Arts and SUSU students, as it was a powerful cultural and educational driver. Acquaintance with author's fine and exalted images brings about the idea that, apart from the surrounding routine, there is a spiritual space and that the creative space is an eternal world that has no boundaries.

Collection of works by artist Valentin Kachalov was showcased in the monographic exhibition "On the Heavenly and Earthly". The subjects of these works may be divided into two groups - mosaic icon images and stilllife paintings by the artist. In line with the title of the exposition, the author demonstrates the importance of both godly spiritual images and fragments of the household, the beauty of which is brilliantly depicted by the artist. The exhibition was an introduction to the Christian culture in its modern understanding subject to centuries-old traditions, but existing in the present. "Christian Subject in Works of Art by Chelyabinsk Artists" was a major exposition that showcased creative works of many artists. The exhibition comprised paintings, graphics and sculptures. It is a bright example of a very reverent attitude of creative minds towards the Christian subject. Another aspect of the spiritual identity development was a monographic exhibition by ceramic sculptor and painter Elena Schetinkina "Creative Philosophy According to N.A. Berdyaev". The works of the cycle represent graphical sheets and decorative porcelain. They are very unusual in terms of execution and embedded meaning. They received very warm welcome at the university, were interpreted and experienced in the entirety of their artistic content.

Expositions of works by Ural artists that have nation-wide importance deserve special attention. South Ural pictural art of 1940-1990 was represented by the exhibition titled "Road of Heart" from the private collection of Yu.T. Ageev. It helped understand that the art of Chelyabinsk is a part of the home cultural heritage that features a high artistic and historical value. A key work in this respect was the one by B.V. Ryabinin dedicated to South Urals female athlete L.P. Skoblikova the only six-times Olympian world champion in speed skating, Honoured Master of Sports of the Soviet Union.

The beauty of the South Ural nature in the context of events from the Russia's historical past was depicted in the exhibitions "My Varlamovsky Pine Wood" and "The Past Before My Eyes..." of Lyudmila Kostina. L.N. Kostina's view of the world as a person and artist was born and built in close connection with the space and time of her childhood, youth and maturity. The artist's creative works embody enormous love for the Ural nature and deep emotions related to the tough periods of the Russian history. Exhibition by Vladimir Bubnov "Among Lakes and Mine Rocks..." showcased the paintings and graphic works showing the artist's impressions of the country's nature and extensive artistic experience. The artist depicts the nature of the Ural and Siberia, Crimea and Baikal, Volga and Baltic. His paintings demonstrate the Ural artist's internal connection with the grand art of the 
country thus presenting students a picturesque image of the Ural and other regions of Russia.

The tradition to exhibit local artists' works at SUSU started with the exhibition "Landscape in the Creative Works of Russian Artists". The collection of works by Ural, St. Petersburg and Moscow artists allows show the peculiarities of their emotional view of the South Ural nature in one exhibition. Students' acquaintance with the artistic image of the nature of their native land ensures their emotional attachment to the South Ural. At the exhibition, Valentin Kachalov presented "Open Cut" painting (1989) to the university having thus laid the foundation for the collection of the SUSU Art Museum.

The exposition of paintings by V. Shapovalov attracts special attention. The artist presented students 20 landscapes depicting the South Ural nature in the author's very modern and rich style. This act has become a part of the university's history and evidence of the artist's civil consciousness and public spirit. It should be noted that the SUSU Art Museum that has more than 700 exhibits sets up the collection of the modern Ural art on the university's premises, which serves as the basis for research and education activities. It settles yet another task preservation of outstanding works of art by South Ural artists of the XX-XXI centuries. The most pieces of art have been presented by artists.

Exhibitions of paintings by landscapepainter Viktor Skobelev "View of the World" "Spring-Fall 2009" and "God's Summertime" are bright examples of monographic expositions. In different years, the Hall of Arts was able to receive artist's works, which allowed students to get acquainted with his creative work on the university premises. Demonstration of emotionally strong paintings drawn in an unusual manner has enhanced the youth's experience as far as the modern state of the regional artistic culture is concerned.
The Hall of Arts houses commemorative exhibitions. One of them, "To the Memory of the Artist", comprised the works by Viktor Merkulov (1960-2000), so that visitors of the Hall of Arts could appreciate not only the development of artist's skills, talent and creative views over all these years, but also the contribution made by the artist into the artistic and cultural life of the South Ural. The exhibition titled "The Great Attic" that combined the works by Konstantin Fokin and his seven students is an example of collaboration between the Hall of Arts and a group of young artists. Visiting students got familiar with the attributes of the artistic school set up at the Chelyabinsk State Institute of Culture. The exhibition was a brilliant example of collaboration of the two higher educational establishments of Chelyabinsk and proved that the Hall of Arts served the aim of the cultural consolidation of creative powers of Chelyabinsk.

Another element of the cultural identity implemented in exhibitions is national and ethnical. Works by Zainulla Latfulin ("Painting and Graphics", "Ural Masters of Arts") are not only intertwined with the history of the Ural region, but also showcase artist's personality features - life and art values. The students who visited the exhibition got to know ethnical peculiarities of the South Ural landscape embodiment. The graphic exposition by Bashkir artist Farid Ergaliev "To the Beat of Time" comprises 36 sheets of black-and-white graphics that were made by the artist for the exhibition in Chelyabinsk. In his creative work, Ergaliev has established his own system of symbols backed by available folk décor elements having thus brought together the heritage of the past and the living spirit of the present.

The exhibitions reviewed show the variety of genres, directions and schools of the Ural fine art; almost all the leading South Ural artists are presented in the expositions. Exhibition themes 
combine the main elements of the cultural identity. The artists' works with particular success form studentship's cultural regional identity. The works exhibited in the Hall of Arts unveil the common historical past of the region, its myths, legends and symbols. Acquaintance with the artists, images of their characters, their memorization instills respect towards outstanding leaders and pride for the South Ural. Students' involvement in the culture of the region that reflects its history, fate and creative achievements is an important factor. Thus, vocational education is harmonically backed with the knowledge of peculiarities of the artistic life of the native land and enhances the students' overall cultural and aesthetical level. Thanks to exhibition activities of the SUSU museum, students may contemplate the artistic image of their native land and get involved with the culture and traditions of the South Ural.

\section{Reference}

Alaudinov, A.A. (2012). Regional'naya identichnost' kak osnova formirovaniya obshchenatsional'noy politicheskoy identichnosti [Regional identity as the basis for the formation of a nationalpolitical identity], Moscow, $128 \mathrm{p}$.

Kolesnik, M.A. (2014). Spetsifika obshcherossiyskoy i regional'noy kul'turnoy iden-tichnosti studentov Sibirskogo federal'nogo universiteta na osnove rezul'tatov assotsiativnogo eksperimenta so slovom «Rodina» [Specificity of the All-Russian and Regional Cultural Identity of the Students of the Siberian Federal University on the Basis of the Results of the Associative Experiment with the Word "Rodina"], In Sovremennyye problemy nauki i obrazovaniya [Modern problems of science and education], 4, available at: www.science-education.ru/ru/article/view?id=14016

Koptseva, N.P. (2013). Formirovaniye rossiyskoy natsional'noy identichnosti i voz-mozhnosti filosofii N.O. Losskogo dlya ratsional'nogo konstruirovaniya kontsepta «Natsiya» [Formation of the Russian national identity and the possibility of the philosophy of N.O. Lossky for the rational design of the concept "Nation"], In Sovremennyye problemy nauki i obrazovaniya [Modern problems of science and education], 6, available at: www.science-education.ru/ru/article/view?id=10561

Korobeynikova O.M. (2010). Tvorchestvo A.P. Kudryavtseva v kontekste osnovnykh tendentsiy razvitiya otechestvennoy keramiki vtoroy poloviny XX - nachala XXI vv. [Kudryavtseva in the context of the main tendencies of development of domestic ceramics of the second half of the XX early XXI centuries], In Vestnik Yuzhno-Ural'skogo gosudarstvennogo universiteta. Ser.: Sotsial'nogumanitarnyye nauki [Bulletin of the South Ural State University. Ser .: Social and Human Sciences], $15,74-79$.

Nazukina, M. V. (2010). Regional'naya identichnost' v sovremennoy Rossii: tipologiche-skiy analiz [Regional identity in modern Russia: typological analysis], Perm’, 200 p.

N.V. Parfentjeva (2009). K razrabotke kontseptsii vystavochnoy i obrazovatel'noy deyatel'nosti universitetskogo zala iskusstv [On the Elaboration of a Concept of Exhibition and Education Activities of the University Hall of Arts], In Vestnik Yuzhno-Ural'skogo gosudarstvennogo universiteta. Ser.: Sotsial'no-gumanitarnyye nauki [Bulletin of the South Ural State University: Social and Humanitarian Sciences], 12, 57-63.

Parfentjev N.P. (2010). Kontseptsiya muzeya nauki i iskusstva Yuzhno-Ural'skogo gosudarstvennogo universiteta [Concept of the Science and Art Museum of the South Ural State University], Nauchno-metodicheskoye obespecheniye deyatel'nosti universitetskogo muzeya iskusstv v 
sfere khudozhestvenno-esteticheskogo obrazovaniya i vospitaniya studenchestva: materialy regional. nauch.-prakt. konf [Scientific and Methodological Support of Operations of the University Art Museum in Art and Aesthetic Education and Training of the Studentship: materials of the Regional Research and Practice], 12-19.

Parfentjeva N.V. (2010). O printsipakh formirovaniya resursnoy bazy khudozhestvennoesteticheskogo obrazovaniya studenchestva na primere sozdaniya khudozhestvennoy kollektsii universitetskogo Muzeya iskusstv [On the Principles of Creating the Resource Base for Art and Aesthetic Education and Training of the Studentship as Exemplified by the Art Collection of the Art Museum], In Vestnik Yuzhno-Ural'skogo gosudarstvennogo universiteta. Ser.: Sotsial'no-gumanitarnyye nauki [Bulletin of the South Ural State University: Social and Humanitarian Sciences], 14, 55-62.

N.V. Parfentjeva (2009). Osnovnyye napravleniya deyatel'nosti universitetskogo muzeya iskusstv i ikh nauchno-metodicheskoye obespecheniye [Basic Directions of Activity of the University Art Museum and their Scientific and Methodological Support], In Vestnik Yuzhno-Ural'skogo gosudarstvennogo universiteta. Ser.: Sotsial'no-gumanitarnyye nauki [Bulletin of the South Ural State University: Social and Humanitarian Sciences], 13, 48-51.

Parfentjev N.P. (2010). Sotrudnichestvo Yuzhno-Ural'skogo gosudarstvennogo universiteta i vedushchikh uchrezhdeniy iskusstv i kul'tury v sfere esteticheskogo vospitaniya studenchestva [Cooperation between the South Ural State University and Leading Art and Cultural Institutions in Aesthetic Education of the Studentship], Nauchno-metodicheskoye obespecheniye deyatel'nosti universitetskogo muzeya iskusstv $v$ sfere khudozhestvenno-esteticheskogo obrazovaniya $i$ vospitaniya studenchestva: materialy regional. nauch.-prakt. konf [Scientific and Methodological Support of Operations of the University Art Museum in Art and Aesthetic Education and Training of the Studentship: materials of the Regional Research and Practice], 86-92.

Parfentjeva N.V., Parfentjev N.P. (2010) University Art Museum: the Basic Directions of Activity and Their Scientific and Teaching Aids, In Journal of Siberian Federal University. Humanities \& Social Sciences, 3, (3), 412-420.

Rusanova, A.G. (2007) Osobennosti kul'turnoy identichnosti studentov v oblastnom tsentre Rossii [Features of cultural identity of students in the regional center of Russia], Moscow, 152.

Trifonova G.S. (2009). Nauchno-metodicheskiye podkhody i printsipy v uchebno-obrazovatel'noy deyatel'nosti khudozhestvennogo muzeya YUUrGU. Na primere raboty nad vystavkoy «Vasiliy Andreyevich Neyasov (1926-1984). Vossoyedineniye volzhskikh narodov s Rossiyey, 1948-183: istoriya nenapisannoy kartiny» [Scientific and Methodological Approaches in Training and Education Activities of the SUSU's Art Museum. Exemplified by the exhibition "Vasiliy Andreevich Neyasov (1926-1984). Reunion of Volga Peoples with Russia, 1948-183: A Story of a Painting that Has Never Been Drawn], In Vestnik Yuzhno-Ural'skogo gosudarstvennogo universiteta. Ser.: Sotsial'no-gumanitarnyye nauki [Bulletin of the South Ural State University: Social and Humanitarian Sciences], 32, 69-82.

Trifonova G.S. (2009). Podlinnoye iskusstvo v prostranstve vuza: k formirovaniyu kontseptsii sotrudnichestva universitetskogo i gosudarstvennykh khudozhestvennykh muzeyev [True Art on the University Premises: on the Establishment of a Concept of Co-operation between University and State Museums of Fine Arts], In Vestnik Yuzhno-Ural'skogo gosudarstvennogo universiteta. Ser.: Sotsial'no-gumanitarnyye nauki [Bulletin of the South Ural State University: Social and Humanitarian Sciences], 12, 78-82. 


\section{Конструирование культурной идентичности студенчества \\ в процессе выставочной деятельности \\ университетского художественного музея}

\section{С.Д. Ворошин}

Южно-Уральский государственный университет (национальный исследовательский университет) Россия, 454080, Челябинск, пр. Ленина, 76

В работе рассмотрен феномен культурной идентичности студенчества, определяется роль университетского музея в её формировании. На примере Зала искусств Южно-Уральского государственного университета проиллюстрировано влияние экспозиционной деятельности на конструирование различных уровней культурной идентичности студенчества. Проведён анализ выставок южно-уральских художников, прошедших в университете, показана их роль в общенациональном и региональном аспекте культурной жизни вуза.

Ключевые слова: университетские музеи, художественные выставки, формирование культурной идентичности, художники Южного Урала.

Научная специальность: 24.00.01 - теория и история культуры. 